\title{
Photochemical Reactions of Microcystin-LR Following Irradiation with UV Light
}

\author{
Yoshihiro Mizukami \\ Faculty of Liberal Arts and Education, Shiga University, Otsu, Japan \\ Email:mizukami@edu.shiga-u.ac.jp
}

How to cite this paper: Mizukami, Y. (2016) Photochemical Reactions of Microcystin-LR Following Irradiation with UV Light. Open Journal of Physical Chemistry, 6, 79-85.

http://dx.doi.org/10.4236/ojpc.2016.64008

Received: September 16, 2016

Accepted: October 22, 2016

Published: October 25, 2016

Copyright $\odot 2016$ by author and Scientific Research Publishing Inc. This work is licensed under the Creative Commons Attribution International License (CC BY 4.0).

http://creativecommons.org/licenses/by/4.0/

\begin{abstract}
Photochemical reactions of microcystin-LR, a toxic compound produced by some blue green algae, were investigated. Ultraviolet absorption of microcystin-LR was assessed. Time-dependent density functional theory (TDDFT) calculations indicated that absorption peak at $238 \mathrm{~nm}$ was mainly due to excitation of electrons from the linear chain structure Adda of microcystin-LR. Irradiation of microcystin-LR with UV light resulted in the reduction of the $238 \mathrm{~nm}$ absorption peak and the appearance of a new peak at $300 \mathrm{~nm}$. Density functional theory (DFT) and TDDFT calculations with a model molecule suggested that this $300 \mathrm{~nm}$ peak was due to tricyclo-Adda microcystin-LR, an intermediate in photochemical reactions of microcystin-LR. Analysis of the rate of this photochemical reaction showed that it was a first order reaction.
\end{abstract}

\section{Keywords}

Microcystin-LR, UV Irradiation, UV Spectra, DFT Calculations, Photochemical Reactions

\section{Introduction}

Eutrophication of fresh water resources often causes algae blooms of blue-green algae. Some species of blue-green algae produce toxic compounds called microcystins [1], which are cyclic polypeptides containing seven amide acids. The structure of one of these microcystins, microcystin-LR, is shown in Figure 1.

Microcystins are characterized by a linear chain structure called Adda (3-amino-9methoxy-2,6,8-trimethyl-10-phenyl-4E,6E-decadienoic acid). Adda plays an important role in their toxicity [2]. UV Irradiation to microcystin formed non-toxic geometrical isomer [4(Z)-Adda] and [6(Z)-Adda] microcystins and toxin was completely decomposed by 10 minutes irradiations [3]. Kaya and Sano reported a photochemical product 
of microcystin-LR by UV irradiation. They identified its structure as tricyclo-Adda microcystin-LR by NMR [2]. However, character of UV spectra for tricycle-Adda microcystin-LR is not reported yet. To further characterize microcystin-LR and its photochemical product, we measured its UV spectrum and the effects of UV irradiation on its spectra over time. We also evaluated the kinetic rate process of this photochemical reaction.

\section{Methods}

Microcystin-LR was obtained from Wako Inc. (Tokyo, Japan). Stock solutions were prepared by dissolving $500 \mu \mathrm{g}$ microcystin-LR in $50 \mathrm{ml}$ water. Aliquots of this solution in silicon cells were irradiated with a UV lamp at a wavelength of $254 \mathrm{~nm}$. The distance between the cell and the lamp was $0.1 \mathrm{~m}$, and power of the UV lamp was $6 \mathrm{~kW}$. The absorption spectra of this solution were obtained after irradiation for 0,15 , and $30 \mathrm{sec}$, and for 1, 3, 5, 10, 15, and $30 \mathrm{~min}$, using a UV-Vis spectrometers (Shimadzu UV mini 1240). The absorbance of the peak at every irradiation time was recorded.

Density functional theory (DFT) [4], [5] calculations at the B3LYP/6-31G(d) level of theory [6], [7] were performed to optimize the Adda fragment model (Figure 2). In this model, carbon, oxygen, nitrogen and hydrogen were colored gray, red, blue and white,

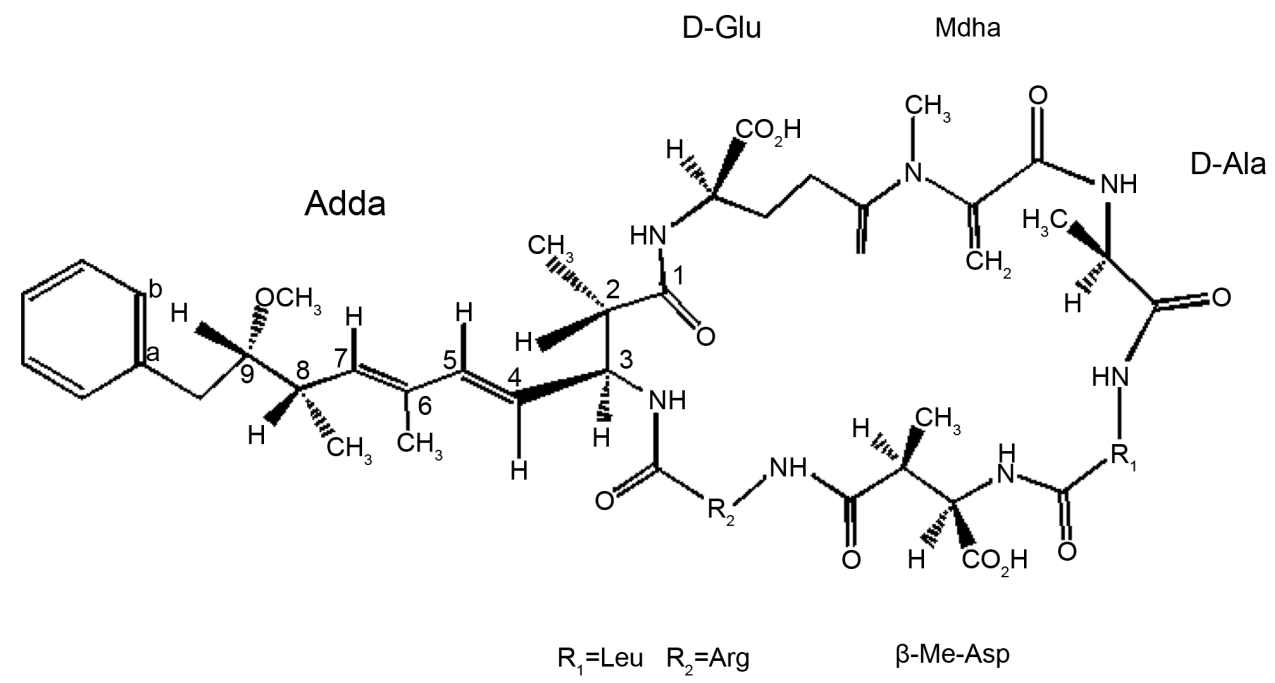

Figure 1. Molecular structure of microcystin-LR.

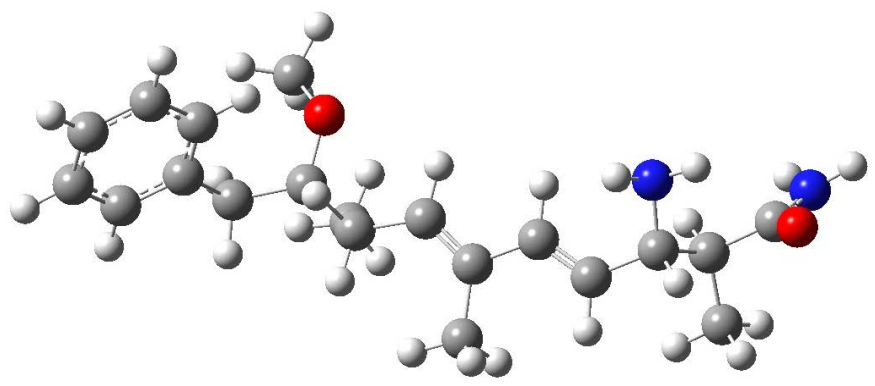

Figure 2. Fragment model of Adda of microcystin-LR. 
respectively and the two termini of Adda fragments were filled with $\mathrm{NH}_{2}$. Time-dependent density functional theory (TDDFT) calculations were used to evaluate excitation energy at the optimized geometry. DFT and TDDFT calculations were performed using the Gaussian 09 program [8]. Similar DFT and TDDFT calculations were used for the fragment model of tricyclo-Adda. Frontier orbitals were obtained for the initial state model of cyclic addition reactions.

\section{Results and Discussions}

The absorption spectra of microcystin-LR after UV irradiation times ranging from $0 \mathrm{sec}$ to $30 \mathrm{~min}$ are shown in Figure 3. In the absence of UV irradiation $(0 \mathrm{sec})$, microcystin-LR showed a peak around $238 \mathrm{~nm}$, which may be due to electron excitation at conjugated diene in Adda [9].

TDDFT calculations of the fragment model of Adda (Figure 2) were performed to theoretically assign the peaks of the absorption spectra. The characteristics of the molecular orbitals (MOs) are shown in Figure 4. MOs of \#90, \#89 and \#91 were the highest occupied MO (HOMO), the next HOMO (HOMO-1) and the lowest occupied MO (LUMO), respectively. The absorption peak of microcystin-LR was mainly attributed to the 4,6-diene of Adda (HOMO-LUMO transition), and partly to the $\mathrm{n} \pi^{*}$ transition from the 3-amino nitrogen of Adda (next HOMO to LUMO transition). The calculated excitation wavelength was $234 \mathrm{~nm}$ and the oscillator strength was 0.48 . In comparison, the experimental peak was around $238 \mathrm{~nm}$.

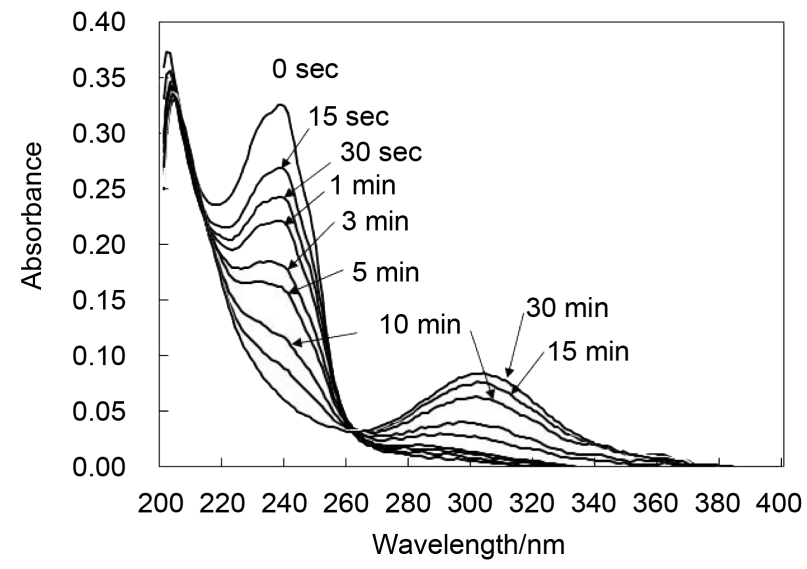

Figure 3. UV spectra of microcystin-LR following irradiation with UV light at $254 \mathrm{~nm}$ for times ranging from $0 \mathrm{sec}$ to $30 \mathrm{~min}$.

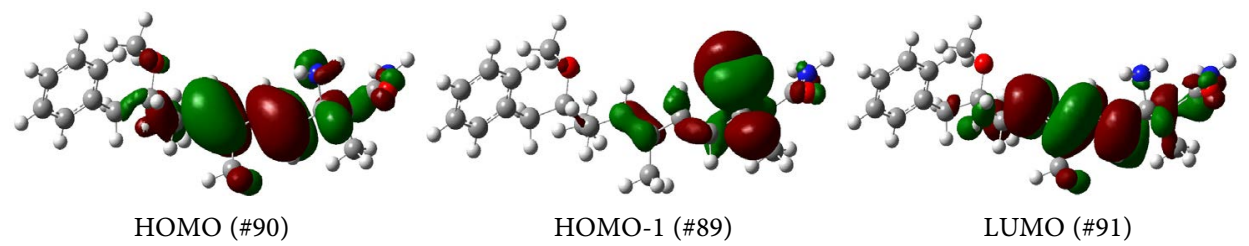

Figure 4. Electron clouds of the highest occupied molecular orbital (HOMO, \#90), the next HOMO (HOMO-1, \#89) and the lowest occupied molecular orbital (LUMO, \#91). 
UV irradiation resulted in a time-dependent reduction in the peak height at $238 \mathrm{~nm}$ and the generation of a new peak at $300 \mathrm{~nm}$. The absorbance of this $300 \mathrm{~nm}$ peak increased gradually over time, with a maximum at $30 \mathrm{~min}$ (Figure 3 ). The variations over time in UV spectra resulted in an isobestic point, indicating that two molecular species contributed to the absorption spectra. This $300 \mathrm{~nm}$ peak likely represents an intermediate compound in the photochemical reaction.

Nodularin is a cyclic polypeptide with five amide acids and a molecular structure is very similar to that of microcystin-LR. Both compounds have Adda. UV spectra of nodularin also have a peak at $238 \mathrm{~nm}$, which is likely due to electron excitation at diene in the Adda region. Irradiation of aqueous solutions of nodularin with UV light of $254 \mathrm{~nm}$ wavelength was reported to result in a reduction of $238 \mathrm{~nm}$ peak and concomitant increase at $300 \mathrm{~nm}$ in nodularin concentration [10]. Similar to nodularin, we found that irradiation of microcystin-LR with UV light at $254 \mathrm{~nm}$ reduced the peak at $238 \mathrm{~nm}$ and increased the peak at $300 \mathrm{~nm}$. Twist and Codd did not refer to the assignment of 300 $\mathrm{nm}$ peak of nodularin with UV irradiation in [10]. Because Adda is common to microcystin-LR and nodularin, we hypothesized that the peak at $300 \mathrm{~nm}$ originated from Adda.

UV irradiation of microcystin-LR was reported to yield a photochemical product called tricyclo-Adda microcystin-LR (Figure 5) [2], resulting from the intramolecular cyclic addition of Adda.

The phenyl double bond (sites a and $\mathrm{b}$ in Figure 1) attacks the double bond (sites 7 and 6 in Figure 1) in Adda, forming a tricyclic structure (sites 1', 7', 5' and 6' in Figure 5). TDDFT calculations were performed to determine the excitation energy of tricyclo-Adda fragment model (Figure 6). The theoretical excitation energy was found to be $281 \mathrm{~nm}$, comparable with the peak at $300 \mathrm{~nm}$ determined experimentally. The experimental ratio of the oscillation strength of the $300 \mathrm{~nm}$ peak to the $238 \mathrm{~nm}$ peak was 0.23 ,

\section{Tricyclo-Adda}

D-Glu Mdha

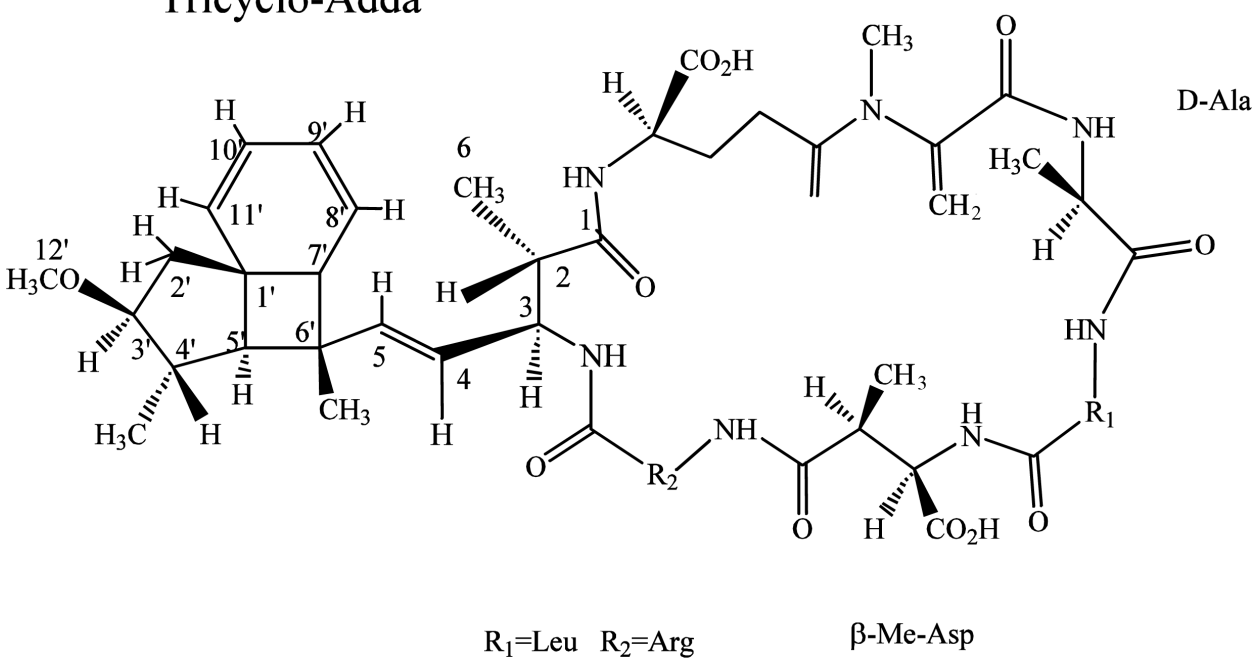

Figure 5. Structure of tricyclo-Adda microcystin-LR. 
comparable to the theoretically calculated oscillation strength of 0.16 .

Frontier orbitals are known to play an important role in cycloaddition reactions. Overview from theoretical aspect was reported [11]. To confirm the occurrence of this photochemical cycloaddition reaction, we checked the frontier orbitals of the initial state model (Figure 7) of this reaction. LUMO is shown in Figure 8. The double bond in Adda interacts with that in a phenyl group to create bonds. The activity of LUMO appeared in an exited state, induced by irradiation with UV light.

To determine the reaction rate, the logarithm of absorbance at $238 \mathrm{~nm}$ was plotted relative to time (Figure 9). The linearity was very good, indicating that the rate of this

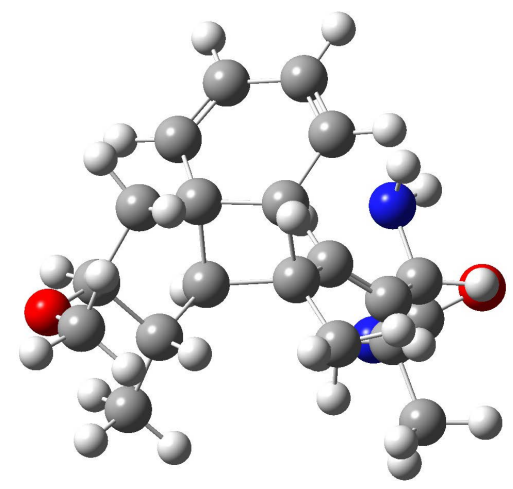

Figure 6. Fragment model of tricyclo-Adda.

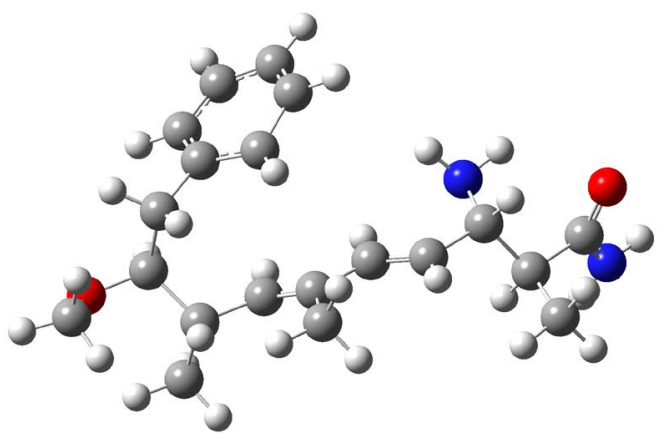

Figure 7. Initial state model for the cycloaddition reaction of Adda.

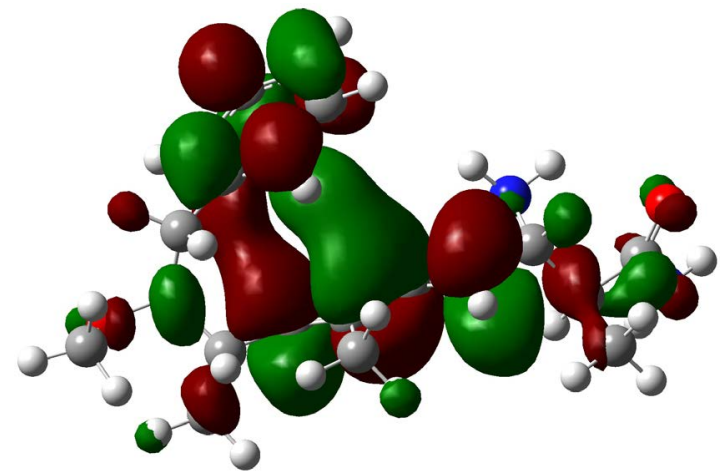

Figure 8. Lowest occupied molecular orbital (LUMO) of the initial state model for the cycloaddition reaction of Adda. 


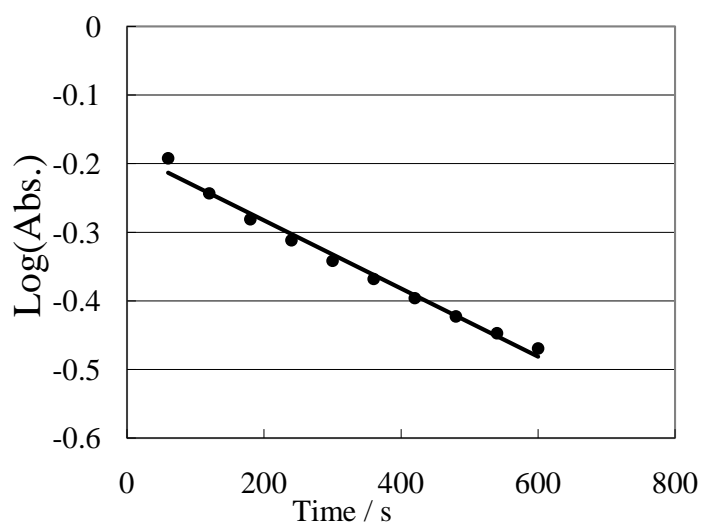

Figure 9. Plot of logarithm of absorbance at $238 \mathrm{~nm}$ vs. time of irradiation.

photoreaction met first order kinetics. This analysis did not include the peak at $0 \mathrm{sec}$, because its inclusion would have interfered with linearity. This may indicate that the very early stage of this photochemical reaction proceeds via a different mechanism.

\section{Conclusion}

This study investigated the photochemical reaction of microcystin-LR by assessing UV spectra over time following UV irradiation. The origins of the absorption peaks were obtained from the TDDFT calculations with the fragment models of Adda and tricyclo-Adda. The changes in time variation of the $238 \mathrm{~nm}$ peak indicated that this photochemical reaction satisfied first order kinetics.

\section{Acknowledgements}

The author acknowledges Mr. Hideaki Iwasa for his assistance in experiments. This work is partly supported by a Grant-in-Aid for Scientific Research \#09740428 from the Ministry of Education, Science and Culture of Japan.

\section{References}

[1] Watanabe, M.F., Harada, K., Carmichael, W.W. and Fujiki, H., Eds. (1996) Toxic Microcystis. CRC Press, Boca Raton.

[2] Kaya, K. and Sano, T. (1998) A Photodetoxification Mechanism of the Cyanobacterial Hepatotoxin Microcystin-LR by Ultraviolet Irradiation. Chemical Research in Toxicology, 11, 159-163. http://dx.doi.org/10.1021/tx970132e

[3] Tsuji, K., Watanuki, T., Kondo, F., Watanabe, M.F., Suzuki, S., Nakazawa, H., Suzuki, M., Uchida, H. and Harada, K. (1995) Stability of Microcystins from Cyanobacteria II. Effect of UV Light on Decomposition and Isomerization. Toxicon, 33, 1619-1631. http://dx.doi.org/10.1016/0041-0101(95)00101-8

[4] Hohenberg, P. and Kohn, W. (1964) Inhomogeneous Electron Gas. Physical Review B, 136, 864-871. http://dx.doi.org/10.1103/PhysRev.136.B864

[5] Kohn, W. and Sham, L.J. (1965) Self-Consistent Equations Including Exchange and Correlation Effects. Physical Review A, 140, 1133-1138.

http://dx.doi.org/10.1103/PhysRev.140.A1133 
[6] Becke, A.D. (1988) Density-Functional Exchange-Energy Approximation with Correct Asymptotic Behavior. Physical Review A, 38, 3098-3100. http://dx.doi.org/10.1103/PhysRevA.38.3098

[7] Lee, C., Yang, W. and Parr, R.G. (1988) Development of the Colle-Salvetti Correlation Energy Formula into a Functional of the Electron Density. Physical Review B, 37, 785-789. http://dx.doi.org/10.1103/PhysRevB.37.785

[8] Frisch, M.J., Trucks, G.W., Schlegel, H.B., Scuseria, G.E., Robb, M.A., Cheeseman, J.R., Scalmani, G., Barone, V., Mennucci, B., Petersson, G.A., Nakatsuji, H., Caricato, M., Li, X., Hratchian, H.P., Izmaylov, A.F., Bloino, J., Zheng, G., Sonnenberg, J.L., Hada, M., Ehara, M., Toyota, K., Fukuda, R., Hasegawa, J., Ishida, M., Nakajima, T., Honda, Y., Kitao, O., Nakai, H., Vreven, T., Montgomery Jr., J.A., Peralta, J.E., Ogliaro, F., Bearpark, M., Heyd, J.J., Brothers, E., Kudin, K.N., Staroverov, V.N., Kobayashi, R., Normand, J., Raghavachari, K., Rendell, A., Burant, J.C., Iyengar, S.S., Tomasi, J., Cossi, M., Rega, N., Millam, J.M., Klene, M., Knox, J.E., Cross, J.B., Bakken, V., Adamo, C., Jaramillo, J., Gomperts, R., Stratmann, R.E., Yazyev, O., Austin, A.J., Cammi, R., Pomelli, C., Ochterski, J.W., Martin, R.L., Morokuma, K., Zakrzewski, V.G., Voth, G.A., Salvador, P., Dannenberg, J.J., Dapprich, S., Daniels, A.D., Farkas, O., Foresman, J.B., Ortiz, J.V., Cioslowski, J. and Fox, D.J. (2009) Gaussian 09, Revision A.02. Gaussian, Inc., Wallingford CT.

[9] Harada, K., Ogawa, K., Matsuura, K., Murata, H., Suzuki, M., Watanabe, M.F., Itezono, Y. and Nakayama, N. (1990) Structrual Determination of Geometrical Isomers of Microcystin LR and RR from Cyanobacteria by Two-Dimensional NMR Spectroscopic Techniques. Chemical Research in Toxicology, 3, 473-481. http://dx.doi.org/10.1021/tx00017a014

[10] Twist, H. and Codd, G.A. (1997) Degradation of the Cyanobacterial Hepatotoxin, Nodularin, under Light and Dark Condition. FEMS Microbiology Letters, 151, 83-88. http://dx.doi.org/10.1111/j.1574-6968.1997.tb10398.x

[11] Hirao, H. and Ohwada, T. (2005) Theoretical Revisit of Regioselectivities of Diels-Alder Reacions: Orbital-Based Reevaluation of Multicenterd Reactivity in Terms of Reactive Hybrid Orbitals. Journal of Physical Chemistry A, 109, 816-824.

http://dx.doi.org/10.1021/jp048111y

\section{Submit or recommend next manuscript to SCIRP and we will provide best service for you:}

Accepting pre-submission inquiries through Email, Facebook, LinkedIn, Twitter, etc. A wide selection of journals (inclusive of 9 subjects, more than 200 journals)

Providing 24-hour high-quality service

User-friendly online submission system

Fair and swift peer-review system

Efficient typesetting and proofreading procedure

Display of the result of downloads and visits, as well as the number of cited articles

Maximum dissemination of your research work

Submit your manuscript at: http://papersubmission.scirp.org/

Or contact ojpc@scirp.org 